\title{
Surgeries under Suspended Animation (Hibernation)
}

\author{
José Luis Mosso Vázquez* \\ School of Medicine, Universidad Panamericana, Mexico City
}

Submission: February 15, 2017; Published: March 30, 2017

*Corresponding author: José Luis Mosso Vázquez, Clínica de Especialidades Alberto Pisanty Ovadía del ISSSTE, Hospital General y Regional Numero 25 del IMSS, Mexico; Email: jmosso@up.edu.mx

\author{
Abstract \\ Following surgical techniques were done under suspended animation in 15 hamsters, open surgeries, NOTUS (Natural Orifice Trans \\ umbilical Surgery), conventional laparoscopy and laparoscopy with smart phones.
}

Keywords: Suspended animation; Hibernation; Laparoscopic surgery; Smart phone

\section{Introduction}

The first idea to offer a Minimally Invasive Anesthesia (MIA) has given by Prof. Richard M. Satava that consider the results of several researchers as Brian M Bames [1] from the Institute of arctic biology, University of Alaska Fairbanks, in the field of suspended animation or hibernation in mammals. Some mammals in active live have heart rate 300 beats per minute, respiratory rate is 150 breaths per minute, body temperature is $37^{\circ} \mathrm{C}$. In hibernating conditions, mammals reduce their metabolic responses as follows; heart rate 3 beats per minute, respiratory rate is $<1$ breaths per minute, body temperature is $<2^{\circ} \mathrm{C}$. The proposal of this idea is to perform surgeries under suspend animation in the future because it represent a challenge to perform Minimally Invasive Surgeries with easy tissue manipulation without bleeding as a big risk in conventional surgical technique (Open, endoscopic surgery or robotic surgery). Many ways have been considered to avoid bleeding risks as new models tools, using computer aided surgery, robots but all of them reduce a little bit this risk. Surgeon has increased his surgical training on virtual or animal models with the same proposal, to avoid in the future risks in real surgeries on humans (Table 1).

Table 1: Surgical time record in four surgical techniques under suspended animation NOTUS (Natural Orifice Trans umbilical Surgery).

\begin{tabular}{|c|c|c|c|c|}
\hline & Open Surgery & NOTUS & Conventional Laparoscopy & $\begin{array}{c}\text { Laparoscopy with Smart } \\
\text { Phones }\end{array}$ \\
\hline Cases & 6 & 7 & 1 & 1 \\
\hline Average surgical time & 16.91 minutes & 13.27 minutes & 23 minutes & 25 Minutes \\
\hline Complications & $\begin{array}{c}\text { One death in the post- } \\
\text { operative }\end{array}$ & & & \\
\hline
\end{tabular}

\section{Methodology}

We induced hibernation on Hamsters (Males mesocricetus auratus hamsters between 180 to 200 grs) under $4^{\circ} \mathrm{C}$ for 30 minutes, darkness and $\mathrm{CO} 2$ into a cooler with $125 \mathrm{ml}$ per minute of $\mathrm{CO} 2$ during 30 seconds [2]. Hamsters presented apnea and we begin the surgery, at the end of each surgery we gave Oxygen a reason of 3 Lt per minute during 4 minutes until complete reestablishment with normal heart rate. Without intravenous

line, just intramuscular dipyrone in the preoperative, abdomen wall was cleaned with benzyl solution and cover the abdomen with surgical and sterilized cloths. In dorsal decubitus for open surgeries, and anti-Trendelenburg positions for laparoscopy, hamsters were positioned. 4 Laparotomies, 1 appendectomy, 1 splenectomy. 7 laparoscopies with NOTUS technique (Olympus endoscopy equipment), 1 conventional laparoscopy, and 1 laparoscopy aided with smart phone (I Phone G6 and no wiring fiber optic Wi-Fi Endoscope camera HD were used) instead of conventional laparoscope, were done on 15 hamsters without no complications in the intra operative. No IV line was used, intramuscular dipyrone was only used in the first 12 cases. Hibernation technique for surgery was began at the school of 
Medicine of Universidad Panamericana in Mexico City in 2010, NOTUS technique at the Pisanty Clinic at the ISSSTE in 2011 and in 2017 we began with conventional laparoscopic surgery and smart phones as laparoscope (Figure 1-4).

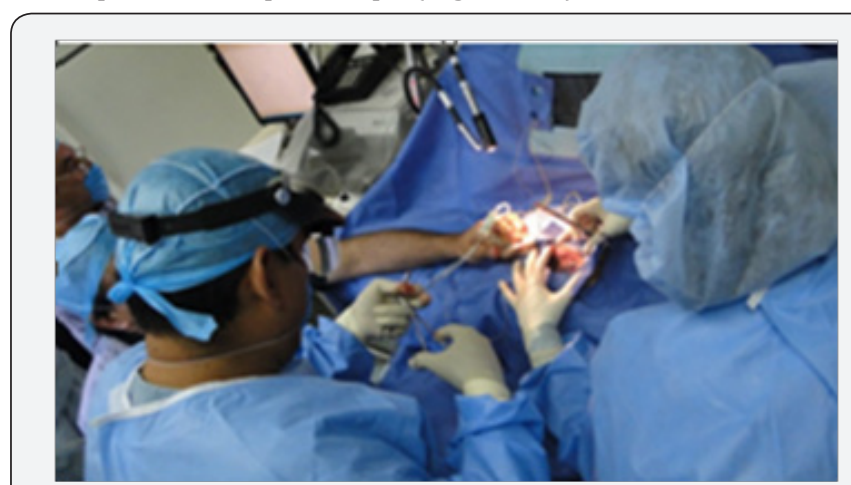

Figure 1: Laparotomy.

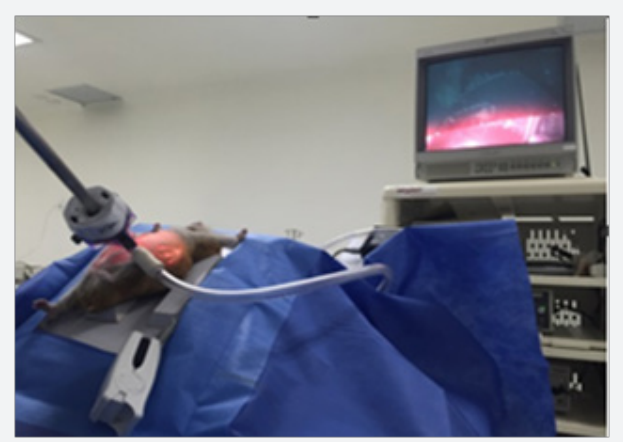

Figure 2: Conventional Laparoscopy.

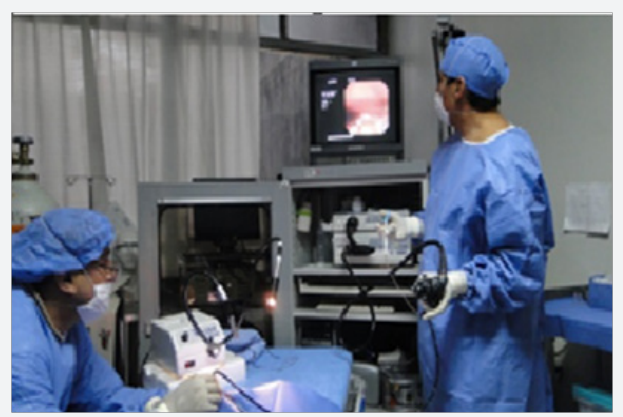

Figure 3: Natural Orifice Trans-sumbilical Surgery "NOTUS".

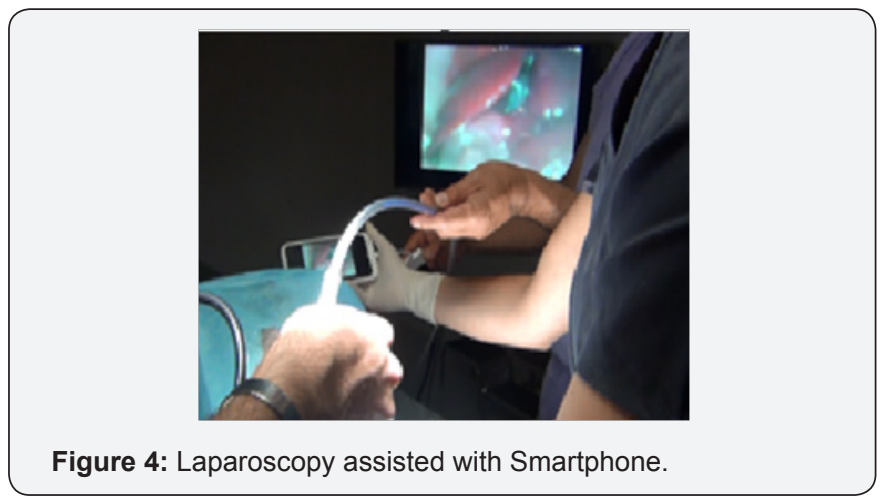

\section{Results}

15 surgeries were done with no complications in the intra operative on 15 hamsters. Average surgical time in open surgery was 16.9 minutes; Average surgical time in NOTUS surgery was 13.27 minutes. Surgical time in conventional laparoscopy was 23 and 25 minutes using smart phone as laparoscope. We did not use intravenous medication without endotraqueal intubation or medication for general anesthesia and equipment. One hamster died in the third day in the postoperative because the abdomen wall was closed with one suture line. The best surgical time was in laparoscopy when we used CO2 for insufflations in pneum operiton eum because there is greater absorption by peritoneum and the suspended animation was longer. Comparative average measures before and during surgeries show us preliminary results as followings: heart rate before 198.6 per minute, heart rate during 166.6 per minute, breathing after 267 per minute, breathing during 82.8 , Temperature before $36.3 \mathrm{oC}$, temperature during $33.7 \mathrm{oC}$, Bleeding $0.4 \mathrm{ml}$, recovery in 3.5 minutes average.

\section{Preliminary Conclusion}

Surgeries under hibernation are possible, where cost benefit is big for under graduate students learning surgeries open and laparoscopic techniques in the Medicine faculty, there is a disadvantage, the short time in suspended animation that we can improve if we use a control $\mathrm{CO} 2$ flow, low temperature and darkness in the intra operative to prolong surgical time, more than 20 minutes. On the other hand, there are many advantages with this technique, for instance, suspended animation avoid intravenous medication and anesthesia equipment investment, with these results we have a complete minimal cost benefit for teaching surgery for universities or faculty of medicine. On the other hand, when we use smart phone as laparoscope we avoid all the conventional laparoscopy equipment except CO2 for insufflations and box laparoscopic instruments. The $\mathrm{CO} 2$ absorbed by the peritoneum permit increase the $\mathrm{CO} 2$ blood concentration levels that facilitate hibernation and permit prolong surgical time and surgeon have more time to review abdominal cavity and manipulate tissue or organs. Laparoscopy view permit us corroborate suspended animation watching heart rate and breathe rate trough the diaphragm. In future works, this application should be used for research in pediatric surgery for children because new born has brown fat as many mammals for example bears and others. In the future, we must improve also this technique having better control of vital signs, serum levels of $\mathrm{CO} 2$ and other tests and $\mathrm{CO} 2$ flow to control suspended animation and prolong surgical time in the intra operative. We suggest $\mathrm{CO} 2$ flow in the intra operative if hamster weak up and oxygen to apply to the hamster with a mask in case of respiratory depression and to weak up in the end of each procedure. Body hamster's temperature breathing and heart rate as well as environment temperature, $\mathrm{CO} 2$ concentration and darkness are an approach of suspended animation or hibernation description as Professor Dr. Professor Richard Satava and Brian M Bames 
said above [3], because the breathing and heart rate are higher in this project, but hamster's condition allow us perform surgical procedures.

\section{References}

1. Niemegeers CJ, Schellekens KH, Van Bever WF, Janssen PA (1976) Sufentanil, a very potent and extremely safe intravenous morphinelike compound in mice, rats and dogs. Arzneimittelforschung 26(8): 1551-1556.

2. Zollner C, Schafer M (2008) [Opioids in anesthesia]. Der Anaesthesist 57(7): 729-740.

3. Bovill JG, Sebel PS, Stanley TH (1984) Opioid analgesics in anesthesia: with special reference to their use in cardiovascular anesthesia. Anesthesiology 61(6): 731-755.

4. Bhavsar R, Sloth E, Folkersen L, Greisen JR, Jakobsen CJ (2011) Sufentanil preserves hemodynamics and left ventricular function in patients with ischemic heart disease. Acta Anaesthesiol Scand 55(8): 1002-1009.

5. Hughes MA, Glass PS, Jacobs JR (1992) Context-sensitive half-time in multicompartment pharmacokinetic models for intravenous anesthetic drugs. Anesthesiology 76(3): 334-341.

6. Bailey PL, Streisand JB, East KA, East TD, Isern S, et al. (1990) Differences in magnitude and duration of opioid-induced respiratory depression and analgesia with fentanyl and sufentanil. Anesth Analg 70(1): 8-15.

7. Brinkers M, Pfau G, Voigt A, Schneemilch C (2015) [Pain therapy in patients with schizoaffective disorder and cancer]. Schmerz 29(2): 217-222.

8. Finnerup NB, Otto M, McQuay HJ, Jensen TS, Sindrup SH (2005)
Algorithm for neuropathic pain treatment: an evidence based proposal. Pain 118(3): 289-305.

9. Knotkova H, Fine PG, Portenoy RK (2009) Opioid rotation: the science and the limitations of the equianalgesic dose table. J Pain Symptom Manage 38(3): 426-439.

10. Fine PG, Portenoy RK (2009) Establishing "best practices" for opioid rotation: conclusions of an expert panel. J Pain Symptom Manage 38(3): 418-425.

11. Freye E, Latasch L (2003) [Development of opioid tolerance -. molecular mechanisms and clinical consequences]. AINS 38(1): 14-26.

12. Schuler M, Griessinger N (2015) [Opioids for noncancer pain in the elderly]. Schmerz 29(4): 380-401.

13. Aubrun F, Bunge D, Langeron O, Saillant G, Coriat P, et al. (2009) [Postoperative morphine administration in the elderly patient]. Anesthesiology 99(1): 160-165

14. Redding SE, Liu S, Hung WW, Boockvar KS (2014) Opioid interruptions, pain, and withdrawal symptoms in nursing home residents Clin Ther 36(11): 1555-1563

15. Kroll W, List WF (1997) Pain treatment in the ICU: intravenous, regional or both? Eur J Anaesthesiol Suppl 15: 49-52.

16. Whipple JK, Lewis KS, Quebbeman EJ, Wolff M, Gottlieb MS, et al. (1995) Analysis of pain management in critically ill patients. Pharmacotherapy 15(5): 592-599.

17. Fragen RJ (1997) Pharmacokinetics and pharmacodynamics of midazolam given via continuous intravenous infusion in intensive care units. Clin Ther 19(3): 405-419.

18. Martin J, Franck M, Sigel S, Weiss M, Spies C (2007) Changes in sedation management in German intensive care units between 2002 and 2006: a national follow-up survey. Crit Care 11(6): R124.

\section{Your next submission with Juniper Publishers} will reach you the below assets

- Quality Editorial service

- Swift Peer Review

- Reprints availability

- E-prints Service

- Manuscript Podcast for convenient understanding

- Global attainment for your research

- Manuscript accessibility in different formats ( Pdf, E-pub, Full Text, Audio)

- Unceasing customer service

Track the below URL for one-step submission https://juniperpublishers.com/online-submission.php 